\title{
Managed aquifer recharge: study of undisturbed soil column tests on the infiltration and treatment capacity using effluent of wastewater stabilization pond
}

\section{Recarga gerenciada de aquíferos: estudo em amostras indeformadas de solo sobre a capacidade de infiltração e de tratamento de efluente de lagoa de estabilização}

\author{
Jaqueline Vígolo Coutinho ${ }^{1}$, Cristiano das Neves Almeida ${ }^{1}$, Eduardo Bernardo da Silva ${ }^{2}$, Catalin Stefan ${ }^{2}$, \\ Gilson Barbosa Athayde Júnior ${ }^{1}$, Carmem Lúcia Moreira Gadelha ${ }^{1}$ and Florian Walter ${ }^{3}$ \\ ${ }^{1}$ Universidade Federal da Paraíba, João Pessoa, PB, Brazil \\ ${ }^{2}$ Technische Universität Dresden, Dresden, Germany \\ ${ }^{3}$ Georg-August-University Göttingen, Göttingen, Germany \\ E-mails: jaqueline.vigolo@gmail.com (JVC); almeida74br@yahoo.com.br (CNA); edubernardo@gmail.com (EBS); \\ catalin.stefan@tu-dresden.de (CS); gilson@ct.ufpb.br(GBAJ); carmemgadelha@yahoo.com.br (CLMG); \\ florian.walter@geo.uni-goettingen.de (FW)
}

Received: April 18, 2018 - Revised: July 19, 2018 - Accepted: September 16, 2018

\begin{abstract}
Managed Aquifer Recharge (MAR) is a useful tool for the treatment and use of sewage effluent because it complements conventional treatment, recovers the aquifer and minimizes risk of saltwater intrusion. This study aims to investigate technical data to determine the treatment of wastewater stabilization pond effluent using undisturbed soil columns collected from a coastal watershed study area within the BRAMAR (BRAzil Managed Aquifer Recharge) project. The treatment efficiency was monitored by measuring physico-chemical parameters $\left(\mathrm{BOD}_{5}, \mathrm{COD}, \mathrm{DOC}\right.$, TSS, $\mathrm{NH}_{3}$ and $\left.\mathrm{NO}_{3}\right)$ in two columns filled with undisturbed sandy soil in which sewage effluent was infiltrated under unsaturated condition for 72 days with an average input flow of $10 \mathrm{~mm} \mathrm{~h}^{-1}$. Results indicated reduction greater than $60 \%$ of organic matter, suspended solids and ammoniacal nitrogen. However, high concentrations of nitrate in the outflow were detected originating from nitrification of ammoniacal nitrogen. Moreover, difficulties in relation to soil clogging were observed. Furthermore, this study brought relevant contributions to understanding the influence of the infiltration rate and ability to treat effluent from wastewater stabilization ponds using undisturbed soil columns. Future research should be undertaken to improve the pretreatment methods and the operation of a MAR system in the study area.
\end{abstract}

Keywords: Managed aquifer recharge; Infiltration rate; Clogging.

\section{RESUMO}

A Recarga Gerenciada de Aquífero (RGA) é uma ferramenta útil para tratamento complementar aos convencionas, recarga de aquíferos, e contenção da intrusão salina. Este trabalho objetiva verificar a capacidade de infiltração e o tratamento do efluente de lagoa de estabilização, em colunas com amostras indeformadas de solo, retiradas em uma bacia hidrográfica litorânea de estudo do projeto BRAMAR (BRAzil Managed Aquifer Recharge). Para isso, a taxa de infiltração e eficiência de tratamento, através do monitoramento de parâmetros físico-químicos ( $\mathrm{DBO}_{5}, \mathrm{DQO}, \mathrm{COD}, \mathrm{SST}, \mathrm{NH}_{3} \mathrm{e} \mathrm{NO}_{3}$ ), foram medidas em 2 colunas, preenchidas com solo predominantemente arenoso, ao longo de 72 dias, em condição não saturada do solo, e uma vazão média de entrada de $10 \mathrm{~mm} \mathrm{~h}^{-1}$. Resultados mostraram remoção superior a $60 \%$ da matéria orgânica, sólidos suspensos e nitrogênio amoniacal. Todavia, foram detectadas altas concentrações de nitrato no filtrado que podem ser devido à nitrificação do nitrogênio amoniacal. Também foram observadas dificuldades quanto à colmatação do solo. Por fim, constataram-se importantes informações sobre a capacidade de infiltração e o tratamento de efluente de lagoa de estabilização usando colunas com amostras indeformadas de solo. Futuras pesquisas devem ser realizadas para aprimorar os métodos de pré-tratamento e de adequada operação da RGA na área de estudo.

Palavras-chave: Recarga gerenciada de aquífero; Taxa de infiltração; Colmatação. 
Managed aquifer recharge: study of undisturbed soil column tests on the infiltration and treatment capacity using effluent of wastewater stabilization pond

\section{INTRODUCTION}

Several studies have been performed in arid and semi-arid regions with the aim of creating alternatives to attenuate the social and environmental problems related to water scarcity. In order to reset water in its natural cycle, the use of treated effluent has been considered as a suitable alternative. Regarding the use of treated wastewater, Sautchúk et al. (2004) have stated that the investment in this option has been growing from 1990s, driven by increasingly stringent environmental requirements and costs associated to the effluent's treatment and appropriate framework of effluent quality to be discharged into water bodies.

A promising effluent use option is through the application to soil infiltration basins, which can both reduce the environmental risks associated with direct release of effluent into water bodies and provide aquifer recharge. This is one of the driving concepts of the Managed Aquifer Recharge - MAR (KANAREK; MICHAIL, 1996; VANDERZALM et al., 2015; SCANLON et al. 2016; WANG et al., 2018). The MAR technique can be a full tool for effluent use by providing complementary effluent treatment, increasing the availability of water in aquifers and providing a front safety factor to soil subsidence and saltwater intrusion (SILVA et al., 2006; SPRENGER et al., 2017; ZHENG et al., 2018). Fernández-Escalante et al. (2014) reported on the costs for several MAR techniques in Spain. They found monetary values less than those needed to build dam for surface reservoirs (about 75\% less) and for drilling wells (about 75\% less).

Some studies with satisfactory results on MAR have been reported in Brazil (FREITAS et al., 2012; SANTOS et al., 2014; MELO et al., 2014), in which techniques such as bank filtration and rainwater harvesting were used. By the other side, these types of investigations are not widespread, and in some cases, they are inconclusive for the following reasons: i) surface sealing soil layers studied, ii) lack of a proper monitoring of the soil, iii) lack of sites where to apply the effluents, or even by iv) the lack of knowledge of the of most aquifers' behavior. Therefore, the need for more research exists in Brazil to better support the treatment capacity through the soil, as well as its maintenance (OKPALA, 2011; SANTOS; LOPES, 2013; CHAVES et al., 2016; COELHO et al., 2018; MACEDO et al., 2018).

Conducting tests on soil columns is one of the ways of evaluating the soil's capacity to treat an effluent. According to Lewis and Sjöstrom (2010), soil columns are blocks of soil that can be laid in a laboratory or in the field and which enable the infiltration monitoring or control and the permeate collection, without losses caused by permeability of the columns' material. The tests on soil columns, which must contain soil samples from a potential area to be used for MAR, consist in their feeding with a percolating solution (GILBERT et al., 2014; REGNERY et al., 2016; SILVA; ALBUQUERQUE; SCALIZE, 2016). The use of undisturbed soil samples is a viable option that warranties a good representation of the natural environment (GILBERT et al., 2014). Studies carried out in Brazil with undisturbed soil samples related to MAR were not found.

Among the information that can be collected in an undisturbed soil column test are: infiltration rate, water treatment capacity and clogging occurrence. Soil clogging consists in a process that reduces the infiltration rate and the duration of a
MAR system (FERNÁNDEZ-ESCALANTE; PRIETO-LEACHE, 2013). This type of phenomenon is common in MAR systems and according to Hutchison, Milczarek and Banerjee (2013), can occur in both superficial layers (accumulation of biofilm and solid particles) and deeper layers (soil sediments with organic and inorganic particles). It is a complex process that may have physical, chemical and biological origin, in which new combinations emerge from the interactions in soil-groundwater-atmosphere (FERNÁNDEZ-ESCALANTE et al., 2016). Several authors have been studying the types of clogging and its attenuation techniques (ANDELMAN et al., 1994; MIOTLIŃSKI et al., 2010; RINCK-PFEIFFER et al., 2013; SMITH, 2014; VYMAZAL, 2018; YADAV; MATHUR; YADAV, 2018).

This article is a product of the international cooperation project of research and technological development between Germany and Brazil (BRAMAR Project-BRAzil Managed Aquifer Recharge) that has started in 2014 and is focusing on the study areas located in the states of Paraíba, Pernambuco and Rio Grande do Norte, Northeast Brazil. The BRAMAR project aimed at proposing strategies for water shortages attenuation and to ensure the sustainable development in the semi-arid region of Northeast Brazil, as well as to increase mutual contribution between German and Brazilian research institutes for the development of integrated water resources management.

Expected BRAMAR project contribution are: planning and preparation of MAR operation schemes that mitigate the water shortage, recover the static level of the water table, improve the quality of effluent and control saltwater intrusion. In this context, this study aims to investigate the soil infiltration capacity and treatment process that the effluent of a facultative stabilization pond (local wastewater treatment plant) undergoes in undisturbed soil columns. These columns were taken from a coastal river basin in the BRAMAR study area, in order to verify the technical feasibility of using a MAR system in the coastal region of Northeast Brazil.

\section{STUDY AREA}

The BRAMAR project study area of João Pessoa, Paraíba (JPA), covers two main river basins: low Paraíba and Gramame. This area covers the municipalities of Cabedelo, João Pessoa, Bayeux, Santa Rita, Cruz do Espírito Santo, São Miguel de Taipu, Conde and Pedras de Fogo. For the limits of this study, only the coastal basin of the Gramame river was considered, from where the undisturbed soil samples (A and C) were collected (Figure 1).

Gramame river basin (GRB) is located between the south latitude coordinates of $7^{\circ} 10^{\prime}$ and $7^{\circ} 40^{\prime}$ and west longitude of $80^{\circ} 34^{\prime}$ and $35^{\circ} 20^{\prime}$. The drainage area of the river basin is $589.1 \mathrm{~km}^{2}$. The main watercourse is the Gramame river $54.3 \mathrm{~km}$ long. The Köppen climate classification indicates a tropical rainy climate in the region, without cold periods and with predominant rain during autumn-winter. The average annual temperature is greater than $26^{\circ} \mathrm{C}$, with annual rainfall ranging between 1400 and $1800 \mathrm{~mm}$ (SEMARH, 2000). 

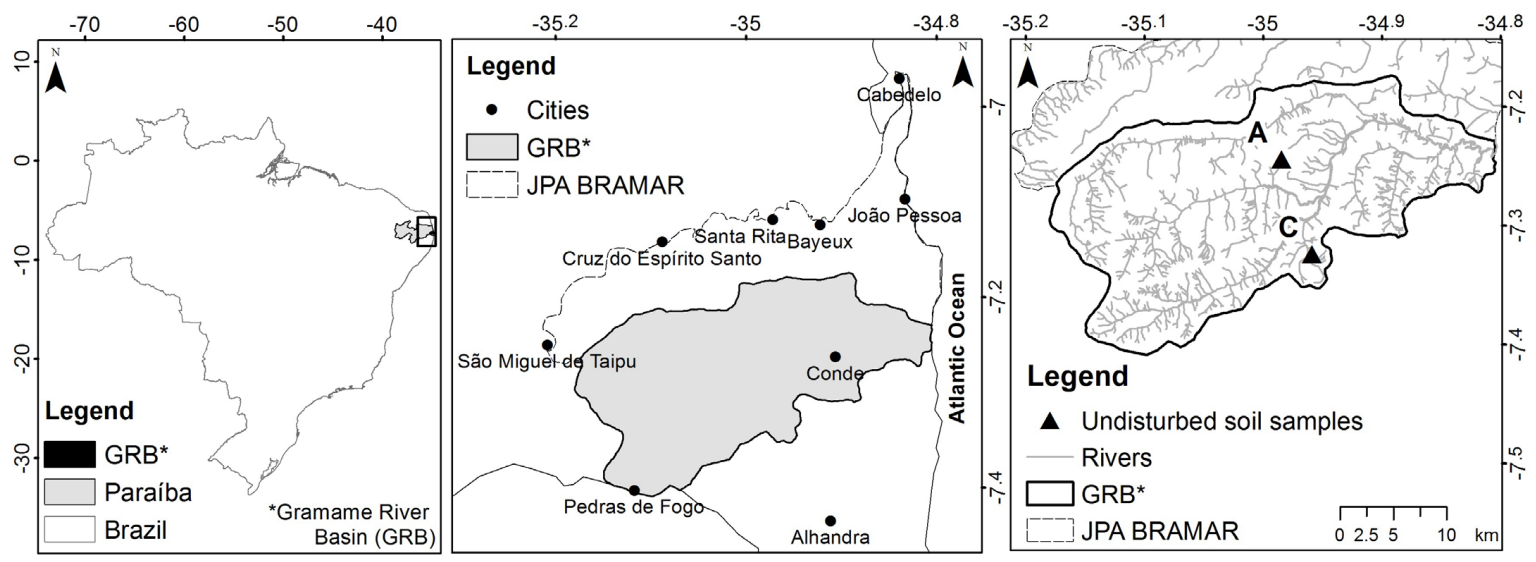

Figure 1. Gramame river basin (GRB) in the JPA BRAMR Project study area.

\section{MATERIALS AND METHODS}

\section{Sampling and collection of undisturbed soil samples}

The experiment was carried out with two undisturbed soil samples taken from two separate locations at GRB, one being in the area adjacent to cultivation of pineapple (column A) (Figure 2) and the other adjacent to corn cultivation (column C) (Figure 3).

The undisturbed samples were collected with stainless steel columns $(65 \mathrm{~cm}$ high and $10 \mathrm{~cm}$ in diameter $)$ inserted in the ground after superficial debris removal, without rotation, with the aid of a hammer. After sticking the column until approximately $5 \mathrm{~cm}$ was left above the ground level, the surrounding soil was removed, and the column was manually collected.

To analyze the particle size distribution and the porosity of the soil used in the experiment, samples were collected adjacent to the place from where the undisturbed soil column were taken, at the depths $0.05 \mathrm{~m}$ and $0.80 \mathrm{~m}$, then were mixed (Table 1).

\section{Soil column test at laboratory}

For the feeding of the columns, the effluent from a facultative stabilization pond was placed in 28-liters plastic boxes. From the boxes, the effluent infiltrated by gravity to the columns, at room temperature, which, in general, was above $20^{\circ} \mathrm{C}$ throughout the experiment (SILVA, 2016). The boxes with the effluent were placed about $1 \mathrm{~m}$ above the top of the columns, with an outlet of $17 \mathrm{~mm}$ in diameter, connected to a silicone hose that allowed flow rate control using chokers. From the hose outlet, the effluent reached the top of the columns by dripping, which could be measured using a volumetric bottle and a timer.

Initially, the columns were continuously fed at the rate of $144 \mathrm{~mL} \mathrm{~h}^{-1}$ (mean value) over 43 days, when the first clogging event occurred. Subsequently, the columns were operated under cycles of dry conditions (no influent) and wet (normal flow rate) as follows: 8 days in dry period, 10 days in wet period, 5 days in dry period and 6 days in wet period, making up 72 days of experiment (Figure 4). The boxes that received the facultative pond effluent were refilled as necessary (10 times during the experiment period).

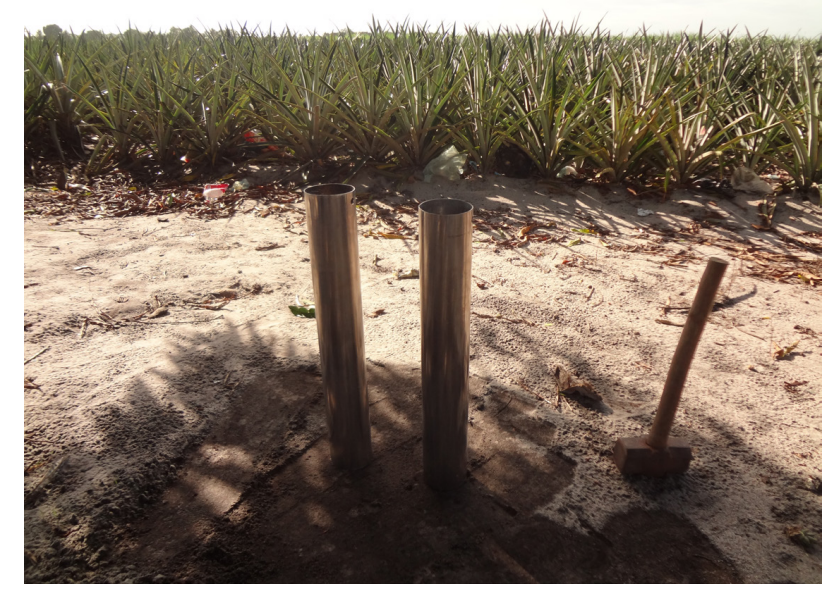

Figure 2. Undisturbed soil column sample collection adjacent to a pineapple crop area.

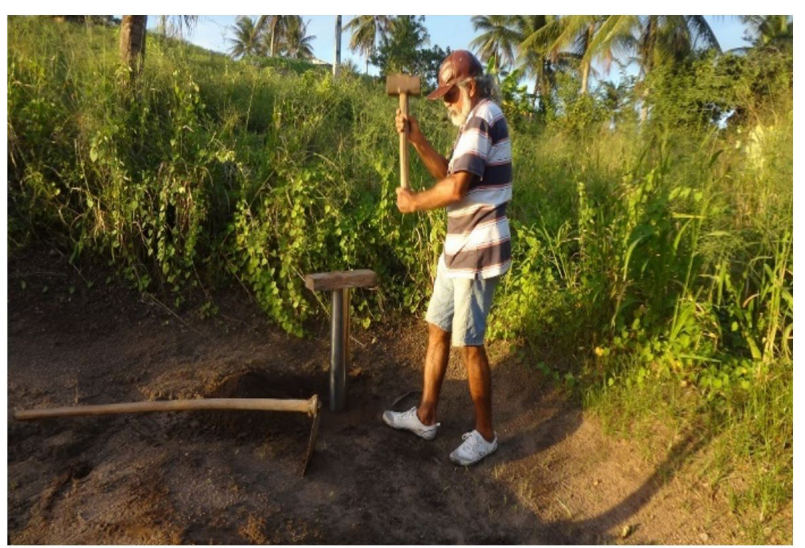

Figure 3. Undisturbed soil column sample collection adjacent to a corn cultivation area.

Table 1. Particle size distribution and mean porosity of the soil.

\begin{tabular}{lrr}
\hline Particle size distribution and porosity & Column A & Column C \\
\hline Gravel $\left(\mathrm{d}^{*}>2 \mathrm{~mm}\right)$ & $1.00 \%$ & $3.00 \%$ \\
Coarse sand $(0.420 \mathrm{~mm}<\mathrm{d} \leq 2 \mathrm{~mm})$ & $43.00 \%$ & $45.00 \%$ \\
Fine sand $(0.074 \mathrm{~mm}<\mathrm{d} \leq 0.42 \mathrm{~mm})$ & $50.00 \%$ & $43.00 \%$ \\
Silt + clay $(\mathrm{d} \leq 0.074 \mathrm{~mm})$ & $6.00 \%$ & $8.00 \%$ \\
Mean porosity & $46.43 \%$ & $51.56 \%$ \\
\hline
\end{tabular}

\footnotetext{
* diameter.
} 
Before the effluent reached the soil column, it passed through a pretreatment installation with the use of geotextile Bidim $^{\circledR}$ and gravel $(1 \mathrm{~cm}$ diameter) arranged on the boxes' outlet. This procedure aimed to retain coarse solids. In addition, aluminium foil was fixed on the outside surface of the boxes to avoid light penetration and excessive microalgae development. The filtrate from the soil columns was diverted to a $1 \mathrm{~L}$ bottle by a silicone hose $(6.5 \mathrm{~mm})$ fitted to an outlet in the lower part of the cylinder. With the volume-filtered values in relation to time, the rate of infiltration was estimated. The general scheme of the test columns can be seen in Figure 5.

\section{Physico-chemical analysis in the feeding wastewater and filtrate liquid}

Physico-chemical analyses were performed in both feeding wastewater (effluent from a facultative waste stabilization pond) and filtrate liquid (soil columns effluent). Feeding samples were identified as number 1 (A1 and C1), while soil columns effluent as the number 2 (A2 and C2). Altogether, four analyses were carried out between $26^{\text {th }}$ July and $13^{\text {rd }}$ September 2016, on a biweekly frequency. An exception for this frequency was the interval between $2^{\text {nd }}$ and $3^{\text {rd }}$ analysis that was 21 days, due to the need to interrupt the inflow because of clogging.

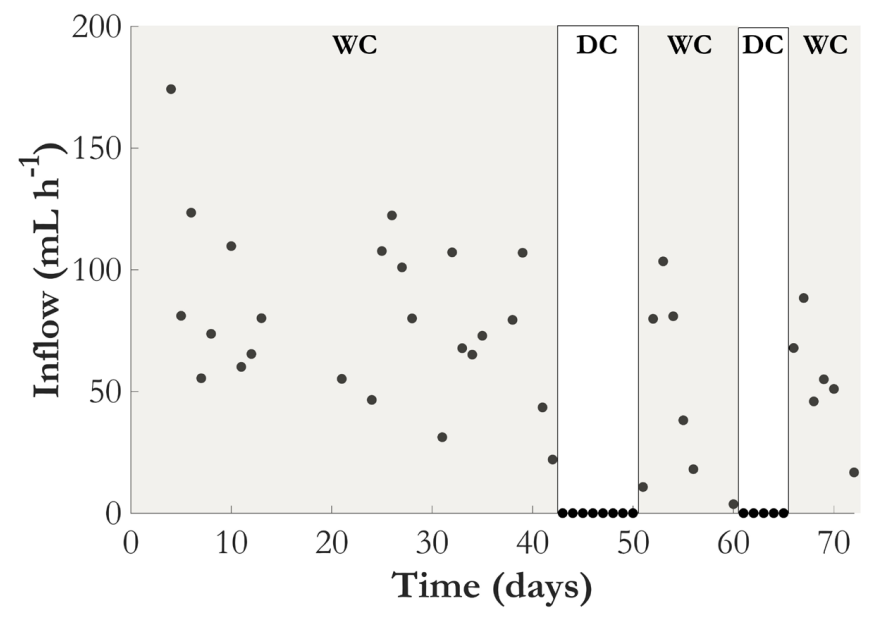

Figure 4. Feeding flow rate during wet (WC) and dry (DC) periods along the experiment in column A.
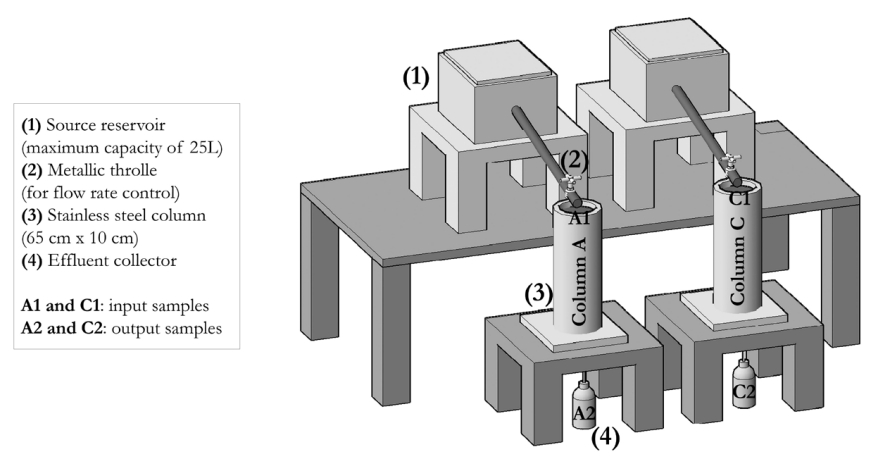

Figure 5. General scheme of soil column tests for this experiment.
Physico-chemical parameters were analyzed using Alfakit ${ }^{\circledR}$, which follows the methodologies adapted from Standard Methods for the Examination of Water and Wastewater (APHA, 2005). The studied parameters were biochemical oxygen demand $\left(\mathrm{BOD}_{5}\right)$, chemical oxygen demand (COD), dissolved organic carbon (DOC), total suspended solids (TSS), ammoniacal nitrogen $\left(\mathrm{NH}_{3}\right)$ and nitrate $\left(\mathrm{NO}_{3}\right)$. $\mathrm{BOD}_{5}$ was analyzed by titration while the DOC followed the direct method patented by Hach Company ${ }^{\circledR}$ for concentrations between 0 and $150 \mathrm{mg} \mathrm{L}^{-1}$ (HACH, 2014).

\section{RESULTS AND DISCUSSION}

\section{Infiltration rate}

Columns $\mathrm{A}$ and $\mathrm{C}$ presented similar infiltration rates, with a mean value of $10 \mathrm{~mm} \mathrm{~h}^{-1}$, for the mean influent rate of $144 \mathrm{~mL} \mathrm{~h}^{-1}$ (Figure 6).

Infiltration rate at the $42^{\text {nd }}$ day in the experiment reduced $49.6 \%$ and $28.7 \%$ for column A and C, respectively, in relation to the previous determination ( $33^{\text {rd }}$ day in the experiment). In the $56^{\text {th }}$ day of experiment, the rate also declined in both columns. This was the consequence of the clogging phenomenon that began to dominate in the soil column, making the interruption of feeding necessary. Therefore, it was decided to start, from the $42^{\text {nd }}$ day of experiment, an alternation between wet and dry cycles. The duration of the dry periods adopted herein were enough to recover soil infiltration capacity. However, these periods were not uniform and must be better studied in future research.

In addition to the alternation of operation cycles, in field situations the clogged layer of soil could be removed, resulting in a recovery of the soil infiltration capacity. However, it was not possible to perform this procedure on the experiment herein described, given the risk of losses of the undisturbed samples, making it necessary to evaluate this additional measure in future research.

\section{Treatment efficiency of the soil columns}

Table 2 presents the arithmetic means and standard deviations for $\mathrm{BOD}_{5}, \mathrm{COD}, \mathrm{DOC}, \mathrm{TSS}, \mathrm{NH}_{3}$ and $\mathrm{NO}_{3}$ for the feeding wastewater and for the effluent of each column. The temporal variations of the same parameters are shown in Figures $7 \mathrm{a}$ to $7 \mathrm{f}$.

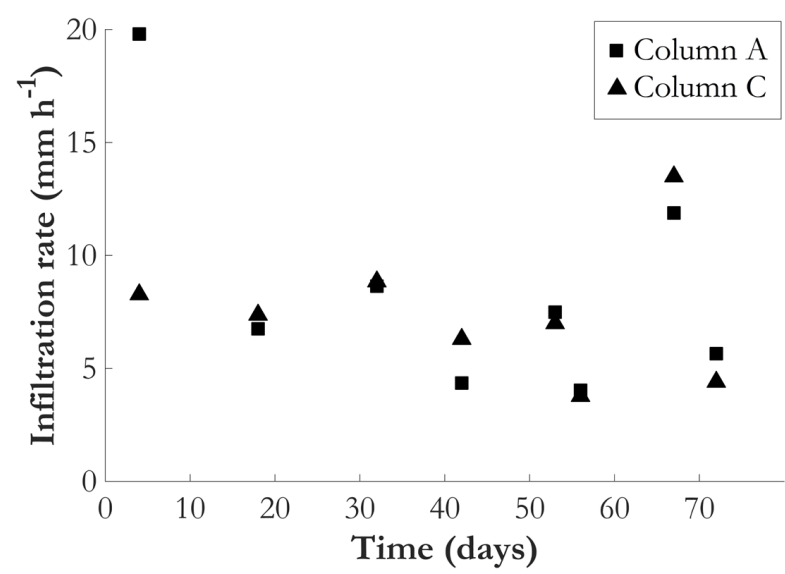

Figure 6. Infiltration rates along the experiment. 
Table 2. Statistics for the physico-chemical parameters.

\begin{tabular}{|c|c|c|c|c|c|c|}
\hline \multirow{2}{*}{$\mathbf{P *}$} & \multicolumn{3}{|c|}{ Column A } & \multicolumn{3}{|c|}{ Column C } \\
\hline & Influent (A1) & Effluent (A2) & $\mathrm{R} * *$ & Influent (C1) & Effluent (C2) & $\mathrm{R} * *$ \\
\hline $\mathrm{BOD}_{5}$ & $15.25 \pm 11.17$ & $2.58 \pm 2.75$ & $83.1 \%$ & $15.40 \pm 8.74$ & $4.45 \pm 5.14$ & $71.1 \%$ \\
\hline $\mathrm{COD}^{5}$ & $69.07 \pm 20.88$ & $51.57 \pm 39.19$ & $25.3 \%$ & $78.13 \pm 21.78$ & $49.18 \pm 20.78$ & $37.0 \%$ \\
\hline DOC & $27.00 \pm 19.47$ & $11.33 \pm 6.66$ & $58.0 \%$ & $14.33 \pm 3.21$ & $20.00 \pm 12.17$ & $-39.5 \%$ \\
\hline TSS & $26.50 \pm 16.42$ & $8.50 \pm 4.20$ & $67.9 \%$ & $25.75 \pm 21.67$ & $9.75 \pm 10.50$ & $62.1 \%$ \\
\hline $\mathrm{NH}_{3}$ & $49.25 \pm 7.00$ & $15.35 \pm 26.53$ & $68.8 \%$ & $44.28 \pm 9.17$ & $19.27 \pm 19.69$ & $56.5 \%$ \\
\hline $\mathrm{NO}_{3}^{3}$ & $1.00 \pm 0.89$ & $5.67 \pm 8.98$ & $-466.2 \%$ & $7.37 \pm 13.26$ & $11.13 \pm 9.69$ & $-51.0 \%$ \\
\hline
\end{tabular}

$* \mathrm{P}$ : parameter; $* * \mathrm{R}=($ Influent-Effluent $) /$ Influent.
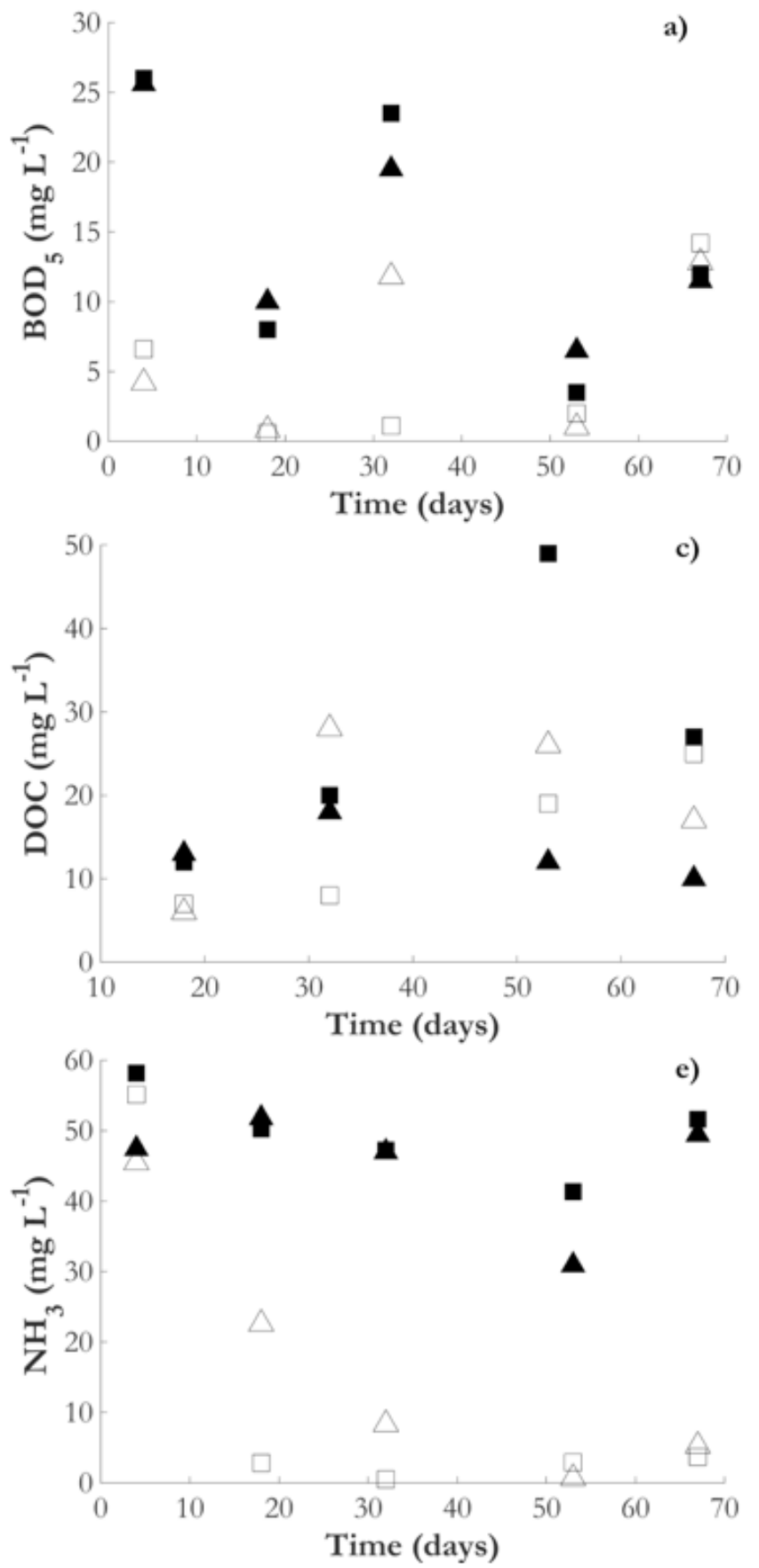
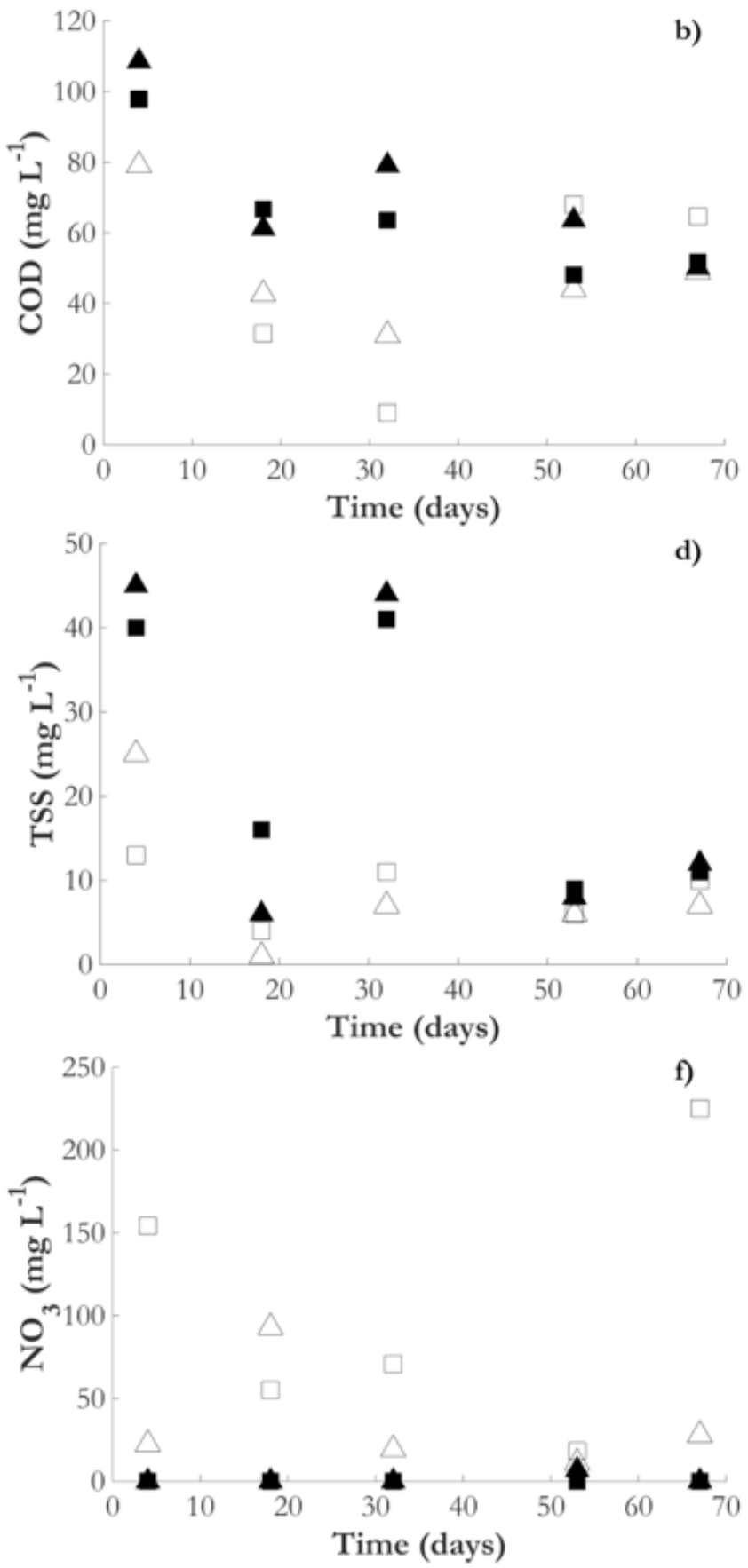

- Column A1 $\square$ Column A2 $\Delta$ Column C1 $\Delta$ Column C2

Figure 7. Temporal variations of physico-chemical parameters in columns A and C. 
The columns produced low values of $\mathrm{BOD}_{5}, \mathrm{COD}$, TSS and $\mathrm{NH}_{3}$ in the effluents, resulting in high removal efficiencies for these parameters and demonstrating the suitability of the soil column as a wastewater treatment option. The values found are like those reported for the effluent of sand filter applied to wastewater treatment (TONON et al., 2015). With respect to DOC concentration, there was removal in column $\mathrm{A}$ and an increase in column $\mathrm{C}$. The organic matter $\mathrm{BOD}_{5}$ and $\left.\mathrm{COD}\right)$ suffered biological oxidation, resulting in $\mathrm{CO}_{2}$, which can be volatilized to the atmosphere or be dissolved in liquid mass. Volatilization of $\mathrm{CO}_{2}$ explains the decrease in DOC in column $\mathrm{A}$, while its retention can explain the observed increase in column $\mathrm{C}$.

For the $\mathrm{NO}_{3}$, there was an increase of its concentration in both columns, what can be explained by the biological process of nitrification, in which $\mathrm{NH}_{3}$ is converted to $\mathrm{NO}_{3}$ by bacteria. The main $\mathrm{NH}_{3}$ source in the facultative pond effluent is the nitrogen associated to the biomass (bacteria, phytoplankton and zooplankton) and residual material (ESTEVES, 1998). This nitrification process was also reported by Diab and Shilo (1998) during dry cycles in infiltration basins.

This kind of analysis of the reduction in the concentration of physico-chemical parameters in the effluent of wastewater stabilization ponds through soil columns emphasizes the importance of assessing the capability of treatment in the soil with other types of effluent, such as the urban drainage and irrigation effluent, for various scenarios in Brazil, as a tool for water resources management. If a MAR system using effluent from a wastewater treatment plant is not possible, other sources, such as rainwater, which has better quality, could be investigated. In the case of using rainwater for this purpose, besides increasing levels of groundwater, there will be a reduction on flooding problems (CADAMURO; CAMPOS, 2005; MONTENEGRO et al., 2005; ALMEIDA, 2011; NUNES, 2017). This type of solution can indeed contribute to the improvement of groundwater quality.

\section{Occurrence of clogging in the soil columns}

After 42 days of experiment, the columns showed a decrease in the infiltration rate that is associated to the clogging in the soil pores. The first hypothesis to cause the clogging is the high concentrations of microalgae, which were found in the feeding effluent (A1 and C1). Figure 8 shows greenish color in membranes that filtered the feeding effluent, due to the presence of microalgae.

High values of TSS (part of which is composed by microalgae) in the $\mathrm{A} 1$ and $\mathrm{C} 1$ samples were found in this analysis in the $32^{\text {nd }}$ day of experiment $\left(41 \mathrm{mg} \mathrm{L}^{-1}\right.$ and $44 \mathrm{mg} \mathrm{L}^{-1}$, respectively). This confirms what had been verified by Silva (2016), that the geotextile bags filled with gravel are not enough for the removal of these particles. According to Bekele et al. (2015), the maximum concentration suggested for TSS to avoid clogging is $5 \mathrm{mg} \mathrm{L}^{-1}$, well below the current quality presented by the facultative stabilization pond effluent used in this study. It calls attention to the physico-chemical characteristics of the effluent to be used for MAR systems, because depending on its quality, complementary treatment must be installed before its application on the soil (RINGLEB; SALLWEY; STEFAN, 2016).

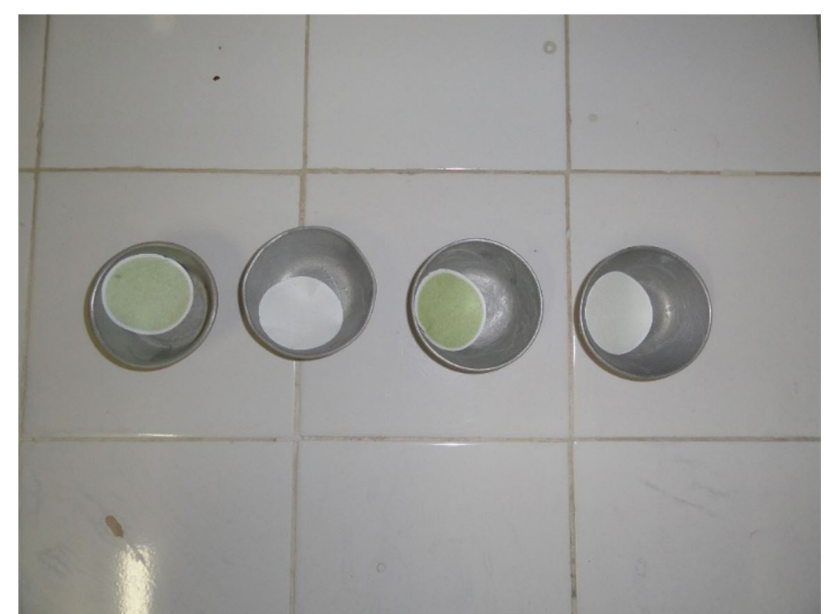

Figure 8. Microalgae retained in membranes that filtered samples from A1 e C1 (first and third filters from the left to the right).

\section{CONCLUSIONS}

Based on this study, it was found, for an average infiltration rate of $10 \mathrm{~mm} \mathrm{~h}^{-1}$, removal efficiencies higher than $60 \%$ for organic matter, suspended solids and ammonia, in the application of facultative waste stabilization pond effluent in undisturbed soil columns. On the other hand, nitrate $\left(\mathrm{NO}_{3}\right)$ concentrations increased, possibly due to the nitrification process.

Problems concerning clogging have been detected in this study due to high concentrations of total suspended solids. As a solution to this phenomenon, alternating between dry and wet cycles restored the soil infiltration capability. A more detailed study should be carried out to determine the proper required range of wet and dry periods. The removal of the upper clogged layer should also be studied for the recovery of the soil infiltration capability in MAR systems.

Finally, it was concluded that the soil of the study area has characteristics of particle size (i.e. predominantly sandy), infiltration capacity and treatment capacity favorable to a Managed Aquifer Recharge facility. However, this approach should be further investigated aiming improvements on the methods of complementary treatment required for facultative waste stabilization pond effluent and on proper operation of the recharge (alternating between dry and wet cycles), that could contribute to the MAR viability.

\section{ACKNOWLEDGEMENTS}

Acknowledgments are due to Financiadora de Estudos e Projetos (FINEP) for supporting BRAMAR project (BRAzil Managed Aquifer Recharge, $n^{\circ} 557 / 2013$ ) and CNPq (Conselho Nacional de Desenvolvimento Científico e Tecnológico) and CAPES (Coordenação de Aperfeiçoamento de Pessoal de Nível Superior) for the concession of scholarships.

\section{REFERENCES}

ALMEIDA, L. Estudo da aplicabilidade de técnicas de recarga artificial de aquiferos para a sustentabilidade das águas termais da região de Caldas Novas - GO. 2011. 147 f. Tese (Doutorado em Geologia) - Instituto de Geociências, Universidade de Brasília, Brasília, 2011. 
ANDELMAN, J.; BAUWER, H.; CHARBENEAU, R.; CHRISTMAN, R.; CROOK, J.; FAN, A.; FORT, D.; GARDNER, W.; JURY, W.; MILLER, D.; PITT, R.; ROBECK, G.; VAUX, H.; VECCHIOLI, J.; YATES, M. Ground water recharge using waters of impaired quality. Washington: National Academy Press, 1994. p 304.

APHA - AMERICAN PUBLIC HEALTH ASSOCIATION. Standard methods for the examination of water and wastewater. American Public Health Association. Washington: APHA, 2005.

BEKELE, E. B.; DONN, M. J.; BARRY, K. E.; VANDERZALM, J. L.; KAKSONEN, A. H.; PUZON, G. J.; WYLIE, J.; MIOTLINSKI, K.; CAHILL, K.; WALSH, T.; MORGAN, M.; MCFARLANE, D.; DILLON, P. J. Managed Aquifer Recharge and Recycling Options (MARRO): Understanding clogging processes and water quality impacts. St Leonards: Australian Water Recycling Centre of Excellence, 2015. 160 p.

CADAMURO, A. L. M.; CAMPOS, J. E. G. Recarga artificial de aqüíferos fraturados no Distrito Federal: uma ferramenta para a gestão dos recursos hídricos. Revista Brasileira de Geociencias, v. 35, n. 3, p. 89-98, 2005. http://dx.doi.org/10.25249/03757536.20053518998 .

CHAVES, H. M. L.; JANKOSZ, A. V.; LUCCHESI, L. A. C.; MARQUES, P. Acurácia do modelo Hydrus na predição da lixiviação de nitrato resultante da aplicação de logo de esgoto tratado a solos de diferentes texturas. Revista Brasileira de Recursos Hídricos, v. 21, n. 1, p. 99-104, 2016. http://dx.doi.org/10.21168/ rbrh.v21n1.p99-104.

COELHO, V. H. R.; BERTRAND, G. F.; MONTENEGRO, S. M.; PAIVA, A. L.; ALMEIDA, C. N.; GALVÃO, C. O.; BARBOSA, L. R.; BATISTA, L. F.; FERREIRA, E. L. Piezometric level and electrical conductivity spatiotemporal monitoring as an instrument to design further managed aquifer recharge strategies in a complex estuarial system under anthropogenic pressure. Journal of Environmental Management, v. 209, p. 426-439, 2018. http://dx.doi.org/10.1016/j. jenvman.2017.12.078. PMid:29309966.

DIAB, S.; SHILO, M. Nitrogen transformation in wastewater reclamation. Water Research, v. 22, n. 5, p. 557-563, 1998. http:// dx.doi.org/10.1016/0043-1354(88)90055-3.

ESTEVES, F. A. Fundamentos de limnologia. Rio de Janeiro: Interciência, 1998. 2. ed. 226 p.

FERNÁNDEZ-ESCALANTE, E.; GIL, R. C.; FRAILE, M. Á. S. M.; SERRANO, F. S. Economic assessment of opportunities for Managed Aquifer recharge techniques in Spain using an advanced geographic information system (GIS). Water, v. 6, n. 7, p. 2021-2040, 2014.

FERNÁNDEZ-ESCALANTE, E.; PRIETO-LEACHE, I. Los procesos colmatantes en dispositivos de gestión de la recarga de acuíferos y empleo de la termografía para su detección y estudio. Un ensayo metodológico en el acuífero "Los Arenales", España.
Boletín de la Sociedad Geológica Mexicana, v. 65, n. 1, p. 51-69, 2013. http://dx.doi.org/10.18268/BSGM2013v65n1a5.

FERNÁNDEZ-ESCALANTE, E.; SAUTO, J. S. S.; GARCÍA, F.G.; SCHÜTZ, C. Types of clogging, distribution and interaction with groundwater quality in an aquifer under long M.A.R. practices. In: ISMAR, 9., 2016, Mexico City, Mexico. Anales... Mexico: UNAM, 2016. Abstract Volume.

FREITAS, D. A.; CABRAL, J. J. S. P.; PAIVA, A. L. R.; MOLICA, R. J. R. Application o $\mathrm{f}$ bank filtration technology for water quality improvement in a warm climate: a case study at Beberibe River in Brazil. Journal of Water Supply: Research \& Technology - Aqua, v. 61, n. 5, p. 319-330, 2012. http://dx.doi.org/10.2166/aqua.2012.097.

GILBERT, O.; HERNÁNDEZ, M.; VILANOVA, E.; CORNELLA, O. Guidelining protocol for soil-column experiments assessing fate and transport of trace organics. Berlin: DEMEAU Project, 2014. p. 1-52.

HACH. Organic Carbon Total. Direct Method. Scope and application: For water, drinking water and wastewater. Method 10173. Test 'N Tubes Vials. Edition 9/2014. Loveland: Hach Company/Hach Lange GmbH, 2014.

HUTCHISON, A.; MILCZAREK, M.; BANERJEE, M. Clogging phenomena related to surface water recharge facilities. In: MARTIN, R. Clogging issues associated with managed aquifer recharge methods. 1. ed. Austrália: IAH Commission on Managing Aquifer Recharge, Australia. p. 95-106. 2013.

KANAREK, A.; MICHAIL, M. Groundwater recharge with municipal effluent: Dan region reclamation project, Israel. Water Science and Technology, v. 34, n. 11, p. 227-233, 1996. http://dx.doi. org/10.2166/wst.1996.0284.

LEWIS, J.; SJÖSTROM, J. Optimizing the experimental design of unsaturated soil columns. In: WORLD CONGRESS OF SOIL SCIENCE "SOIL SOLUTIONS FOR A CHANGING WORLD”, 19., 2010, Brisbane, Australia. Proceedings... Brisbane: WCSS, 2010. p. 1-6.

MACEDO, M. B. D.; LAGO, C. A. F. D.; MENDIONDO, E. M.; SOUZA, V. C. B. D. Performance of bioretention experimental devices: contrasting laboratory and field scales through controlled experiments. Revista Brasileira de Recursos Hidricos, v. 23, p. e3, 2018.

MELO, T. A. T.; COUTINHO, A. P.; CABRAL, J. J. S. P.; ANTONINO, A. C. D.; CIRILO, J. A. Jardim de chuva: sistema de biorretenção para o manejo das águas pluviais urbanas. Ambiente Construido, v. 14, n. 4, p. 147-165, 2014. http://dx.doi.org/10.1590/ S1678-86212014000400011.

MIOTLIŃSKI, K.; BARRY, K.; DILLON, P.; BRETON, M. Alice Springs SAT project bydrological and water quality monitoring report 2008-2009. Canberra: CSIRO, 2010. 
MONTENEGRO, S. G.; MONTENEGRO, A. A.; CAVALCANTI, G. L.; MOURA, A. E. S. Recarga artificial de aquíferos com águas pluviais em meio urbano como alternativa para a recuperação dos níveis potenciométricos: Estudo de caso na planície do Recife (PE). In: SIMPÓSIO BRASILEIRO DE CAPTAÇÃO E MANEJO DE ÁGUA DE CHUVA, 5., 2005, Teresina, PI. Anais... Petrolina: ABCMAC, 2005. Available from: $<$ http://www.abcmac.org.br/files/ simposio/5simp_suzana_recargaartificialdeaquiferoscomaguaspluviais. pdf>. Access on: 20 fev. 2018.

NUNES, M. D. X. Estudo da capacidade de infiltração em sistemas de recarga artificial de aquiferos contaminados no Distrito Federal. $2017.74 \mathrm{f}$. Dissertação (Mestrado em Geociências Aplicadas) - Universidade de Brasília, Brasília, 2017.

OKPALA, W. O. Recarga gerenciada do aquifero do Aeroporto Internacional Governador André Franco Montoro, Guarulbos/SP: estudo piloto do sistema solo-aquífero. 2011. 268 f. Tese (Doutorado em Engenharia) - Escola Politécnica da Universidade de São Paulo, São Paulo, 2011.

REGNERY, J.; WING, A. D.; KAUTZ, J.; DREWES, J. E. Introducing sequential managed aquifer recharge technology (SMART) - From laboratory to full-scale application. Chemosphere, v. 154, p. 8-16, 2016. http://dx.doi.org/10.1016/j.chemosphere.2016.03.097. PMid:27037769.

RINCK-PFEIFFER, S.; DILLON, P.; RAGUSA, S.; HUTSON, J.; FALLOWFIELD, H.; MARSILY, G.; PAVELIC, P. Reclaimed water for aquifer storage and recovery: A column study of well clogging. In: MARTIN, R. Clogging issues associated with managed aquifer recharge methods. 1. ed. Austrália: IAH Commission on Managing Aquifer Recharge, Australia, 2013. p. 25-33.

RINGLEB, J.; SALLWEY, J.; STEFAN, C. Assessment of managed aquifer recharge through modeling - A review. Water, v. 8, n. 12, p. 1-31, 2016.

SANTOS, L. L.; CABRAL, J. J. S. P.; CIRILO, J. A.; FREITAS, D. A.; SENS, M. L.; ARAGAO, R.; BARROS, T. H. S. Aplicação da tecnologia de filtração em margem para população difusa no Semiárido Pernambucano. Revista Brasileira de Recursos Hídricos, v. 19, n. 4, p. 49-58, 2014. http://dx.doi.org/10.21168/rbrh.v19n4. p49-58.

SANTOS, O. G.; LOPES, R. L. Características do solo da área do entorno das valas de infiltração de efluentes da ETE Ponta Negra. In: CONGRESSO DE INICIAÇ AOO CIENTÍFICA DO IFRN, 9., 2013, Currais Novos. Anais... Rio Grande do Norte: IFRN, 2013. Available from: <http://portal.ifrn.edu.br/pesquisa/ editora/livros-para-download/anais-do-ix-congic-ifrn $>$. Access on 15 jan. 2018.

SAUTCHÚK, C. A.; LANDI, F. N.; MIERZWA, J. C.; VIVACQUA, M. C. R.; SILVA, M. C.; LANDI, P. N.; SCHMIDT, W. Conservação e reuso de água: Manual de Orientações para o Setor Industrial. São Paulo: CIRRA/FCTH, 2004.
SCANLON, B. R.; REEDY, R. C.; FAUNT, C. C.; POOL, D.; UHLMAN, K. Enhancing drought resilience with conjunctive use and managed aquifer recharge in California and Arizona. Environmental Research Letters, v. 11, n. 3, p. 1-15, 2016. http:// dx.doi.org/10.1088/1748-9326/11/3/035013.

SEMARH - SECRETARIA EXTRAORDINÁRIA DO MEIO AMBIENTE, DOS RECURSOS HÍDRICOS E MINERAIS DO ESTADO DA PARAÍBA. Plano Diretor da bacia bidrográfica do rio Gramame. João Pessoa: Convênio SEMARH/SCIENTEC, 2000. v. 1-4.

SILVA, E. B. Use of soil column tests in bench scale for assessing the feasibility of a Soil Aquifer Treatment (SAT) with river water and secondary effluent of a Wastewater Treatment Plant in João Pessoa, Paraíba (Brazil). 2016. 67 f. Dissertation (Master in Hydroscience and Engineering). Technische Universität Dresden, Dresden, 2016.

SILVA, F.; ALBUQUERQUE, A.; SCALIZE, P. S. Avaliação da remoção de matéria orgânica e nutrientes por sorção em solos residuais. In: ASSEMBLEIA NACIONAL DA ASSEMAE, 46., 2016, Jaraguá do Sul. Anais... Santa Catarina: ASSAMAE, 2016. Available at http:/ /www.trabalhosassemae.com.br/2016/xxeems/ anais/ANAIS_20_EEMS_ASSEMAE.pdf. Access on 20 feb. 2018.

SILVA, G. E. S.; MONTENEGRO, S. M. G. L.; COSTA, L. M.; MONTENEGRO, A. A. A.; CAVALCANTI, G. Aplicação e modelagem da recarga artificial com águas pluviais para recuperação potenciométrica de aquífero costeiro na Planície do Recife - PE. Revista Brasileira de Recursos Hídricos, v. 11, n. 03, p. 1-10, 2006.

SMITH, L. Clogging mechanisms in Managed Aquifer Recharge: a case study at Mining Area C. 2014. 150 f. Dissertation (Master in Earth and Environment) - The University of Western Australia, Australia, 2014.

SPRENGER, C.; HARTOG, N.; HERNÁNDEZ, M.; VILANOVA, E.; GRÜTZMACHER, G.; SCHEIBLER, F.; HANNAPPEL, S. Inventory of managed aquifer recharge sites in Europe: historical development, current situation and perspectives. Hydrogeology Journal, v. 25, n. 6, p. 1909-1922, 2017. http://dx.doi.org/10.1007/ s10040-017-1554-8.

TONON, D.; TONETTI, A. L.; CORAUCCI FILHO, B.; BUENO, D. A. C. Wastewater treatment by anaerobic filter and sand filter: Hydraulic loading rates for removing organic matter, phosphorus, pathogens and nitrogen in tropical countries. Ecological Engineering, v. 82, p. 583-589, 2015. http://dx.doi.org/10.1016/j. ecoleng.2015.05.018.

VANDERZALM, J. L.; DILLON, P. J.; TAPSUWAN, S.; PICKERING, P.; AROLD, N.; BEKELE, E. B.; BARRY, K. E.; DONN, M. J.; MCFALARNE, D. Economics and experience of managed aquifer recharge (MAR) with recycled water in Australia. $73 \mathrm{p}$. Australia: Australian Water Recycling Centre of Excellence. 2015. 
VYMAZAL, J. Does clogging affect long-term removal of organics and suspended solids in gravel-based horizontal subsurface flow constructed wetlands? Chemical Engineering Journal, v. 331, p. 663-674, 2018. http://dx.doi.org/10.1016/j. cej.2017.09.048.

WANG, F.; VAN HALEM, D.; DING, L.; BAI, Y.; LEKKERKERKER-TEUNISSEN, K.; VAN DER HOEK, J. P. Effective removal of bromate in nitrate-reducing anoxic zones during managed aquifer recharge for drinking water treatment: Laboratory-scale simulations. Water Research, v. 130, p. 88-97, 2018. http://dx.doi.org/10.1016/j.watres.2017.11.052. PMid:29202345.

YADAV, B.; MATHUR, S.; YADAV, B. K. Simulation-Optimization approach for the consideration of well clogging during cost estimation of in situ bioremediation system. Journal of Hydrologic Engineering, v. 23, n. 3, p. 1-10, 2018. http://dx.doi.org/10.1061/ (ASCE)HE.1943-5584.0001622.

ZHENG, G.; CAO, J. R.; CHENG, X. S.; HA, D.; WANG, F. J. Experimental study on the artificial recharge of semiconfined aquifers involved in deep excavation engineering. Journal of Hydrology, v. 557, p. 868-877, 2018. http://dx.doi.org/10.1016/j. jhydrol.2018.01.020.

\section{Authors contributions}

Jaqueline Vígolo Coutinho: experiment performing, data analysis, discussion of the results, preparation of figures/tables and paper writing.

Cristiano das Neves Almeida: responsible and supporting partner of the BRAMAR project (BRAzil Managed Aquifer Recharge), supervisor of the study, structuring and revision of the paper.

Eduardo Bernardo da Silva: conception and design of the experiment and data analysis.

Catalin Stefan: collaborator of the BRAMAR project, conception and design of experiment, and revision of the paper.

Gilson Barbosa Athayde Júnior: supporting partner of the BRAMAR project, discussion of the results, structuring and revision of the paper.

Carmen Lúcia Moreira Gadelha: discussion of the results.

Florian Walter: responsible partner of the BRAMAR project and revision of the paper. 